\title{
Renal manifestations and associated factors among HIV infected children at Muhimbili National Hospital, Dar es Salaam, Tanzania
}

\author{
Francis Fredrick ${ }^{1 *}$, Paschal Ruggajo², Eden E Maro², Bjarne Magnus Iversen ${ }^{3}$, Gopel Basu ${ }^{4}$ \\ From First International Science Symposium on HIV and Infectious Diseases (HIV SCIENCE 2012) \\ Chennai, India. 20-22 January 2012
}

\section{Background}

Human Immunodeficiency Virus infection is a global challenge and sub-Saharan African countries contribute significantly to this pandemic. Children are vulnerable and acquire the infection mostly from their mothers. Highly Active Anti-retroviral Therapy have led to dramatic changes in the incidence of opportunistic infections with reduction in morbidity and mortality, which has paved way for manifestation of non-infectious complications including renal complications. The aim of this study was to determine prevalence of microalbuminuria, proteinuria and associated factors among Tanzanian children.

\section{Methods}

We recruited 240 HIV infected children attending care and treatment clinic. Microalbuminuria and proteinuria were determined by using dipstick and Microalbumin 2-1 combo test strips on spot urine respectively. Serum Creatinine, white blood cell and CD4 counts were determined. Renal ultrasound examinations were also performed.

\section{Results}

Forty nine children (20.4\%) had microalbuminuria and 17 (7.1\%) had proteinuria. Prevalence of proteinuria was significantly higher among children aged 120 months and above ( $p$-value $<0.05)$. Lower CD4 percent $(<25 \%)$ was a risk factor for microalbuminuria $(p$-value $<0.01)$ and proteinuria $(\mathrm{p}<0.01)$. Mean $\mathrm{CD} 4$ count was significantly lower in children with microalbuminuria (pvalue $<0.05)$ and proteinuria ( $\mathrm{p}$-value $<0.001)$. Twenty

\footnotetext{
* Correspondence: fredrick.francis78@gmail.com

'Department of Pediatrics and Child Health, School of Medicine, Muhimbili

University of Health and Allied Sciences, Dar es Salaam, Tanzania

Full list of author information is available at the end of the article
}

eight (11.7\%) children out of 153 had increased cortical echogenicity on ultrasound examination.

\section{Conclusion}

Proteinuria and increased cortical echogenicity were prevalent among HIV infected children who may indicate early onset of renal complications and this call for routine screening for early detection.

\section{Author details \\ 'Department of Pediatrics and Child Health, School of Medicine, Muhimbili University of Health and Allied Sciences, Dar es Salaam, Tanzania. ${ }^{2}$ Department of Internal Medicine, School of Medicine, Muhimbili University of Health and Allied Sciences, Dar es Salaam, Tanzania. ${ }^{3}$ Section of Nephrology, Haukeland University Hospital, Bergen, Norway. ${ }^{4}$ Department of Nephrology, Christian Medical College Vellore, Tamil Nadu, India.}

Published: 4 May 2012

doi:10.1186/1471-2334-12-S1-011

Cite this article as: Fredrick et al:: Renal manifestations and associated factors among HIV infected children at Muhimbili National Hospital, Dar es Salaam, Tanzania. BMC Infectious Diseases 2012 12(Suppl 1):O11.

Submit your next manuscript to BioMed Central and take full advantage of:

- Convenient online submission

- Thorough peer review

- No space constraints or color figure charges

- Immediate publication on acceptance

- Inclusion in PubMed, CAS, Scopus and Google Scholar

- Research which is freely available for redistribution 